\title{
Health Reform Observer - Observatoire des Réformes de Santé
}

\begin{tabular}{l|lll}
\hline Volume 5 & Issue 3 & Article 1 \\
\hline
\end{tabular}

\section{New Policy Directives for the Host Family Program in Ontario}

Deidre Riordon, University of Ottawa, Ottawa, Ontario, Canada

24 September 2017

A Provincial/Territorial Health Reform Analysis

Recommended Citation: Riordon D. 2017. New Policy Directives for the Host Family Program in Ontario. Health Reform Observer - Observatoire des Réformes de Santé 5 (3): Article 1. DOI: https://doi.org/10.13162/hro-ors.v5i3.2867 


\begin{abstract}
The Host Family Program is a provincially-funded residential accommodation program that offers adults with developmental disabilities the chance to live with people who can provide care, support and supervision in a family setting. Individuals with developmental disabilities tend to be at a greater risk for neglect and abuse, so it is imperative that legislation be in place to prevent this from happening. The Host Family Program implemented new policy requirements in April of 2016 in order to increase the safety and security of the people who are in the care of host families. Following a sentinel event that occurred in 2012 in Ancaster, Ontario, a coroner's inquest was conducted and subsequent jury recommendations were made. From these the Ministry of Community and Social Services developed the new policy directives. While the Host Family Program provides housing accommodations to approximately 1,500 people, there are many other vulnerable individuals in several other residential programs and on waiting lists. It is worrisome that there is currently no distinct and separate policy in place to protect these individuals from harm. The policy directives for the Host Family Program are a step in the right direction by government, but further policy development must be achieved in order to prevent future tragedies.

Le programme des services de relève en famille hôte est un programme de logement financé par la province qui permet aux adultes ayant une déficience intellectuelle de vivre avec des personnes qui peuvent offrir des soins, un soutien et une supervision dans un cadre familial. En général, les personnes ayant une déficience intellectuelle courent un plus grand risque d'être négligées et maltraitées ; il est donc impératif que des lois soient mises en place pour empêcher que cela se produise. Le programme des services de relève en famille hôte a mis en oeuvre de nouvelles exigences en avril 2016 afin d'accroître la sûreté et la sécurité des personnes qui vivent dans une famille hôte. Suite à un événement fatal qui a eu lieu à Ancaster, en Ontario, en 2012, une enquête du coroner a été menée et le jury a prescrit plusieurs recommandations. Le ministère des Services sociaux et communautaires a consulté ces recommandations pour développer les nouvelles directives. Même si le programme des services de relève en famille hôte accueille 1.500 personnes, beaucoup de personnes vulnérables relèvent d'autres programmes de logements ou sur des listes d'attente, et il est donc inquiétant qu'il n'y ait actuellement aucune politique spécifique en place pour les protéger. Les nouvelles exigences publiées par le gouvernement pour le programme des services de relève en famille hôte vont dans le bon sens, mais il faut élaborer plus de politiques pour prévenir d'autres tragédies.
\end{abstract}




\section{Key Messages}

- Individuals with developmental disabilities are some of Ontario's most vulnerable citizens and are at an increased risk of neglect and abuse.

- The Ontario Ministry of Community and Social Services has implemented new policy requirements for the Host Family Program.

- The new policy directives represent a response to the tragic death of Guy Mitchell, a man with developmental disabilities who was under the care of a host family.

- Many provinces across Canada have legislation in place that protects all vulnerable adults from harm, but Ontario does not currently have any such legislation.

- The policy directives for the Host Family Program were implemented in April 2016 with the goal of increasing the safety and security of those within the program.

\section{Messages-clé}

- Les personnes souffrant d'une déficience intellectuelle font partie des citoyens les plus vulnérables de l'Ontario et présentent un risque accru d'être victime de négligence et d'abus.

- Le Ministère des Services sociaux et communautaires de l'Ontario a mis en place de nouvelles réglementations pour le programme des services de relève des familles hôtes.

- Ces nouvelles directives réglementaires constituent une réponse au décès tragique de Guy Mitchell, un homme souffrant de déficience intellectuelle confié à une famille hôte.

- Plusieurs provinces canadiennes ont mis en place des législations protégeant les adultes vulnérables mais l'Ontario ne s'est toujours pas doté d'un tel dispositif.

- Les directives réglementaires pour le programme des services de relève en famille hôte ont été mises en place en avril 2016, dans le but d'améliorer la sécurité des bénéficiaires du programme. 


\section{BRIEF DESCRIPTION OF THE NEW POLICY DIRECTIVES}

On 25 September 2015, the Ontario Ministry of Community and Social Services (MCSS) released, for public consultation, a draft of new policy directives for service agencies regarding the Host Family Program, one of several provincially-funded residential housing options available to people with developmental disabilities.

Following the public consultation, the ministry reviewed and analyzed all responses, and revised the draft policy directives. The directives were finalized in March 2016 and distributed to all service agencies that are funded under the Services and Supports to Promote the Social Inclusion of Persons with Developmental Disabilities Act, 2008 (SIPDDA) to provide services and supports for adults with a developmental disability.

The policy directives came into effect in April of 2016 and are intended to strengthen the way service agencies screen, select, and evaluate host families, as well as ensure that the Host Family Program is delivered consistently across Ontario (MCSS 2015a). The policy directives for the Host Family Program replace the existing family home guidelines (MCSS 2004).

\section{HISTORY AND CONTEXT}

Individuals with developmental disabilities are some of our most vulnerable citizens and are at a heightened risk for becoming victims of abuse and neglect (Community Living Ontario 2009; Palusci, Datner, Wilkens 2015). Although research in Ontario is lacking, it has been observed that when people with disabilities are encouraged to talk about maltreatment, almost every one of them has a personal story (Community Living Ontario 2009).

During the 1970s, at the beginning of the movement toward de-institutionalization, services for people with developmental disabilities in Ontario were transferred from the Ministry of Health to the Ministry of Community and Social Services (MCSS 2012). Today, provincially-funded community agencies are responsible for providing residential services and supports to individuals with developmental disabilities along with other services and supports, including community participation supports, caregiver respite, employment supports, and professional and specialized services. Some of the residential accommodations include group homes, specialized residences, and family homes (through the Host Family Program). The Host Family Program enables individuals with developmental disabilities to live with families, who are to provide them with care, support, and supervision within a nurturing environment (MCSS 2015b). The program aims to expand the range of residential choices in the community and to allow the needs of individuals to be addressed in a more personal and flexible manner (MCSS 2004). In 2004, family home guidelines containing recommendations for service agencies were updated by the MCSS. These guidelines were under the authority of the Developmental Services Act, which was replaced by 
the SIPDDA in 2008. It is under the SIPDDA that the new policy directives for the Host Family Program were released, outlining minimum requirements which are enforceable by law, unlike the previous guidelines.

There are approximately 67,000 adults in Ontario who are living with a developmental disability, of which 18,000 are receiving residential supports (MCSS 2015a). In the 2013/14 fiscal year the MCSS spent a total of $\$ 1.16$ billion on residences that provide residential and support services, yet there are still over 14,000 people on the wait list for these services. (Office of the Auditor General of Ontario 2014). This long wait list is another factor that further increases vulnerability to abuse and neglect, as people may be residing in unsafe arrangements. The Host Family Program is the only program affected by the new policy directives and provides housing accommodations to only approximately 1,500 people (MCSS 2015a).

\section{GOALS OF THE NEW POLICY DIRECTIVES}

The primary goal of the policy directives is to increase the safety of adults who live in family homes provided through service agencies that offer the Host Family Program. The requirements are intended to "strengthen the way agencies screen, select and evaluate host families and will ensure that the Host Family Program is delivered consistently across the province" (MCSS 2015a). By fulfilling minimum requirements with regard to screening, provision of services, and oversight, individuals within this program are expected to receive care and support from their host family and to be free from abuse and neglect.

\section{FACTORS THAT INFLUENCED HOW AND WHY}

According to Kingdon (2003), the first stage in the policy process involves agenda setting. In order for an issue to make it onto the government's agenda, an issue must be perceived as a "problem" requiring attention. The problem in the case of the policy directives of the Host Family Program is related to several cases of maltreatment that were covered in the media, and in particular one focusing event; the death of Guy Mitchell. Guy Mitchell, a 38-year-old man with a developmental disability who was in need of support, lived in a home with two others with similar challenges. In April of 2012 his body was found in a cistern on the property of the host's home in Ancaster. According to police, the home was in a "deplorable condition," with no running water and no electricity (Clairmont 2015). A coroner's inquest into his death was undertaken and recommendations by the jury, including some proposed policies, were made to a number of stakeholders, including the MCSS and the Ministry of the Attorney General.

Commitment by the MCSS to improve the Host Family Program is in line with the priorities set forth in 2014 by the Premier of Ontario, Kathleen Wynne, which is seemingly part of the policy stream that contributes to a policy-making window set forth in King- 
don's theory. In her 2014 Mandate Letter to Helena Jaczek, the Minister of Community and Social Services, the Premier stressed the importance of continuing to improve developmental services so that they can help individuals with developmental disabilities live as independently as possible (Government of Ontario 2014). Helena Jaczek stated that "implementing new requirements will help make the program a safer option for individuals", (MCSS 2015a).

Further politics surrounding this issue stem from various community organizations that advocate for better legislation to help prevent situations of abuse and neglect. Community Living Ontario is one such organization that acknowledges how laws and policies can help provide enhanced protection to vulnerable adults. The organization has been active in trying to persuade governments to start filling the gaps in current legislation and to work toward enacting a distinct adult protection policy. A distinct adult protection policy could benefit not only individuals who are involved with the Host Family Program, but also those involved in all residential housing options.

\section{HOW THE POLICY DIRECTIVES WERE ACHIEVED}

On 24 July 2015 the results of the inquest and jury recommendations were released. The MCSS was asked to establish, within six months, a working group to examine best practices and consider several recommendations aimed at enhancing and standardizing the procedure for the screening and approval of host families in Ontario (Ministry of Community Safety and Correctional Services (MCSCS) 2015). Shortly after the results of the inquest were released, the MCSS held consultations with various stakeholders that resulted in the new requirements, which are consistent with several of the jury recommendations (MCSS 2015a). Provincial bodies, including Ontario Agencies Supporting Individuals with Special Needs (OASIS), Community Living Ontario, and the Provincial Network on Developmental Services participated in conference calls held over several weeks to review the draft policy directives (OASIS 2015a). It is unclear to what extent vulnerable individuals and their families were specifically consulted in this process, however, it should be noted that agencies such as Community Living Ontario make it a strategic priority to engage the people that they serve (Community Living Ontario 2017). OASIS, an organization whose member agencies provide over $85 \%$ of all developmental services funded by the MCSS, had already expressed their concern and had stated that they would carefully review each recommendation (OASIS 2015b). On 25 September 2015, over three years after Guy Mitchell's death, the MCSS released the policy directives for the Host Family Program. Community agencies had a very short time period (only until the end of November 2015) to provide feedback to the MCSS and plan for implementation before the new policy requirements were put in place in April 2016.

Other residential programs that fall outside of the Host Family Program will not benefit from these new policy directives. There is currently no standalone legislation in place to 
protect vulnerable adults from abuse and neglect in Ontario, but one of the recommendations that resulted from the Guy Mitchell inquest was to enact such law. Community Living Ontario (2009) has noted that the provinces of Alberta, Manitoba, Nova Scotia, New Brunswick, Prince Edward Island, and Newfoundland each have adult protection laws and suggested that Ontario use these provinces as examples to help move toward enacting similar mechanisms.

The jury's recommendation to create distinct and separate adult protection legislation including the mandatory reporting for all suspected cases of abuse and neglect was directed collectively at the MCSS, the Ministry of the Attorney General, the Office of the Public Guardian and Trustee, and the Province of Ontario. In response to this recommendation, a MCSS working group, including 23 multi-sector members from numerous organizations, advised that no immediate action be taken due to the complexity of the issue (The Vanmeer Free Press 2016). Part of this complexity could be because several government authorities were called upon to act on this recommendation, which would necessitate cross-sectoral collaboration thus causing increased complexity in policy formation. Rather than immediate creation of distinct and separate adult protection laws, the working group made suggestions for strategies that can be implemented right away and steps that can be taken in the future (The Vanmeer Free Press 2016). These suggestions included strengthening the existing processes and supports in hopes that eventually more systemic options are identified (The Vanmeer Free Press 2016). For example, the working group suggested that annual training be in place to reinforce the current requirement, under SIPDDA, to report abuse and neglect to the police as the primary means to investigate abuse (The Vanmeer Free Press 2016).

\section{EVALUATION}

It is early to assess the full impact of the new policy directives for the Host Family Program, as they only came into effect as of April 2016. Challenges in implementing an evaluation process that considers both qualitative and quantitative factors may arise given that this program is provided through multiple service agencies across Ontario. Each individual service agency is responsible for having written policy that adheres to the minimum standards outlined in the policy directives (MCSS 2015b), thus necessitating that each service agency also implement appropriate evaluation tools. Further, the evaluation process should involve input from vulnerable adults that are a part of the program, their families, as well as host families.

Although many of the new requirements in the policy directives provide tools for agencies to evaluate what they do, evaluation is nonetheless difficult. The directives do not address the issue of recruitment and compensation of host families (if compensation is kept low, host families may not provide the best quality care). Also, the directives provide minimal requirements only. According to the MCSS (2015b) however, many service agencies will 
not have difficulties meeting the minimum requirements, arguing that they were already going beyond the outlined expectations and are achieving excellent outcomes for those participating in the program.

\section{STRENGTHS, WEAKNESSES, OPPORTUNITIES AND THREATS}

Table 1 summarizes the strengths, weaknesses, opportunities, and threats of the Policy Directives for the Host Family Program.

Table 1: SWOT Analysis

\begin{tabular}{|c|c|}
\hline STRENGTHS & WEAKNESSES \\
\hline $\begin{array}{l}\text { - The policy directives for the Host Family } \\
\text { Program have the potential to improve the } \\
\text { safety and security of individuals with devel- } \\
\text { opmental disabilities who are living in family } \\
\text { homes within the program. } \\
\text { - The new requirements were created through } \\
\text { consultation with various service agencies. } \\
\text { - The policy directives are in line with the cur- } \\
\text { rent mandate of the MCSS. }\end{array}$ & $\begin{array}{l}\text { - The new policy directives only cover the } \\
\text { Host Family Program and not any other ex- } \\
\text { isting residential programs. } \\
\text { - The time given for agencies to comment on } \\
\text { the policy directives was short (just over two } \\
\text { months). } \\
\text { - There may be some difficulty implement- } \\
\text { ing all the requirements in the policy direc- } \\
\text { tives in each family home situation, espe- } \\
\text { cially when trying to arrange unannounced } \\
\text { evaluation visits. }\end{array}$ \\
\hline
\end{tabular}

\section{OpPORTUNITIES}

THREATS

- The policy directives for the Host Family Program provide the opportunity for the program to be delivered in a consistent manner across Ontario.

- The directives set a good example for other provincially-funded residential programs.

- The program represents a step forward in filling the gap in legislation to help protect vulnerable adults.
- Some service agencies may be resistant to change the way in which they currently deliver the Host Family Program.

- People who are interested in welcoming someone with a developmental disability into their home might perceive the new requirements as barriers. 


\section{REFERENCES}

Clairmont S. 2015. Will Guy Mitchell's death protect the vulnerable? Hamilton Spectator, July 23. http://www.thespec.com/news-story/ 5748220-clairmont-will-guy-mitchell-s-death-protect-the-vulnerable-/, as of 15 October 2015.

Community Living Ontario. 2009. Adults who are vulnerable to abuse and neglect: discussion paper. http://www.communitylivingontario.ca/node/89, as of 25 October 2015.

Community Living Ontario. 2017. 2017-2022 strategic plan. http:// communitylivingontario.ca/about/\#strategic-priorities, as of 15 September 2017.

Government of Ontario. 2014. Mandate letter: Community and Social Services. https://www.ontario.ca/page/2014-mandate-letter-community-and-social-services? ga $=1.50535085 .521977368 .1445003812 \#$ section-0, as of 26 October 2015.

Kingdon JW. 2003. Agendas, alternatives and public policies. 2nd ed. New York: Addison Wesley Educational Publishers.

MCSCS (Ministry of Community Safety and Correctional Services). 2015. Verdict of the coroner's jury (Guy Mitchell inquest). https://www.mcscs.jus.gov.on.ca/sites/default/ files/content/mcscs/docs/ec168353.pdf, as of 15 September 2017.

MCSS (Ministry of Community and Social Services). 2004. Familyhome guidelines. http://www.mcss.gov.on.ca/documents/en/mcss/publications/developmental/ FamilyhomeGuidelines2.pdf, as of 20 October 2015.

MCSS. 2012. From institutional to community living: a history of developmental services in Ontario. http://mcss.gov.on.ca/en/dshistory/index.aspx, as of 20 October 2015.

MCSS. 2015a. Ontario releases new requirements for Host Family Program. $\quad$ http://news.ontario.ca/mcss/en/2015/09/ ontario-releases-new-requirements-for-host-family-program.html? ga=1.51649965. 521977368.1445003812, as of 7 October 2015.

MCSS. 2015b. Policy directives for service agencies regarding the Host Family Program. http://mcss.gov.on.ca/en/mcss/publications/developmentalServices/ hostfamilydirectives/Host_Family_ProgramPolicy_Directives_2016.aspx , as of 15 September 2017.

OASIS (Ontario Agencies Supporting Individuals with Special Needs). 2015a. News digest: Host Family Policy Directives Committee. http://static1.squarespace. com/static/533aeff0e4b07f69c06b1956/t/55e745abe4b09c71afab10f0/1441220011543/ News+Digest.pdf, as of 29 November 2015 . 
OASIS. 2015b. Response to coroner's inquest into Guy Mitchell's death. http:// oasisonline.ca/top-stories/response-to-coroners-inquest-into-guy-mitchells-death/, as of 29 November 2015

Office of the Auditor General of Ontario. 2014. Residential services for people with developmental disabilities. http://www.auditor.on.ca/en/content/annualreports/arreports/ en14/310en14.pdf, as of 15 September 2017.

Palusci VJ, Datner E, Wilkins C. 2015. Developmental disabilities: abuse and neglect in children and adults. International Journal of Child Health and Human Development 8 (4): 407-428.

The Vanmeer Free Press. 2016. Inquest into the death of Guy Mitchell: Ministry of Community and Social Services responses to the jury's recommendations. http://www.vanmeerfreepress.com/wp-content/uploads/2016/07/ MCSS-responses-to-the-recommendations-July-22-2016.pdf, as of 15 September 2017. 